DOI: https://doi.org/10.15688/lc.jvolsu.2017.4.12

UDC 349.3

LBC 67.405я73

\title{
ORGANIZATIONAL AND LEGAL SUPPORT OF THE AGENCIES OF SOCIAL PROTECTION OF THE POPULATION
}

\author{
Yulia S. Gusakova \\ Belgorod State National Research University, Belgorod, Russian Federation \\ Vladislav Yu. Turanin \\ Belgorod State National Research University, Belgorod, Russian Federation
}

\begin{abstract}
Introduction: this article summarizes the legal issues of social protection of the population and contemporary social services system in Russia. For this purpose, the authors consider the concept of social protection and the mechanism of social policy implementation, as well as they mark and structure the basic normative legal acts regulating the complex socio-economic rights to such a level of life, which is necessary for a normal existence, personal development and reproduction. By applying the scientific methods, and first of all, the method of system analysis, it is established that social protection is based on the combination of social and legal guarantees, which provide everyone with real opportunities of realizing their rights, including the socio-economic rights to such a level of life, which is necessary for their normal existence, personal development and reproduction. Results: now one may talk of two levels of legal support of social service in almost all the constituent entities of the Russian Federation: federal and regional ones. But it is not everywhere where a sufficient legal framework and "legal technology" are formed, i.e. there is determined the scope of rights in the field of social services in relation to the specific socio-economic environment. Conclusions: the whole current system of social protection of the population implements its goals and objectives through and within the existing legal forms. In Russia there is a mixed organizational structure of the system of social protection of the population, which uses almost all of the organizational and legal forms existing in the countries with market economy.
\end{abstract}

Key words: social protection, legal coverage, legal and regulatory acts, social service.

УДК 349.3

ББК 67.405 я 73

\section{ОРГАНИЗАЦИОННО-ПРАВОВОЕ ОБЕСПЕЧЕНИЕ УЧРЕЖДЕНИЙ СИСТЕМЫ СОЦИАЛЬНОЙ ЗАЩИТЫ НАСЕЛЕНИЯ}

\footnotetext{
Юлия Сергеевна Гусакова

Белгородский государственный национальный исследовательский университет, г. Белгород, Российская Федерация

\section{Владислав Юрьевич Туранин}

Белгородский государственный национальный исследовательский университет, г. Белгород, Российская Федерация

Введение: в данной статье обобщены вопросы правового обеспечения социальной защиты населения и современной системы социального обслуживания в России. С этой целью авторами рассмотрено понятие социальной защиты, механизм реализации социальной политики, а также обозначены и структурированы основные нормативно-правовые акты, регулирующие комплекс социально-экономических прав на такой уровень жизни, который необходим для нормального существования, развития личности и воспроизводства. С помощью методов научного познания и, прежде всего, метода системного анализа, установлено, что социальная защита основывается на совокупности социальных и юридических гарантий, которые предостав-
} 


\section{ТЕОРИЯ И ПРАКТИКА ГОСУДАРСТВЕННО-ПРАВОВОГО РАЗВИТИЯ}

ляют каждому человеку реальные возможности реализации его прав, в том числе социально-экономических прав на такой уровень жизни, который необходим для нормального существования, развития личности и воспроизводства. Результаты: сейчас можно говорить о двух уровнях правового обеспечения социального обслуживания почти во всех субъектах Российской Федерации: федеральном и региональном. Но не везде сформировалось достаточное правовое поле и «правовая технология», то есть определена сфера действия права в области социального обслуживания применительно к конкретной социально-экономической обстановке. Выводы: вся действующая система социальной защиты населения реализует свои цели и задачи посредством и в рамках сложившихся организационно-правовых форм. В России сложилась многоукладная организационная структура системы социальной защиты населения, в которой используются практически все организационно-правовые формы, существующие в странах с рыночной экономикой.

Ключевые слова: социальная защита населения, правовое обеспечение, нормативно-правовые акты, социальное обслуживание.

\section{Введение}

В современной России спектр социальных услуг в социальных учреждениях выpoc, появились новые направления в работе, изменились цели и задачи социальных подразделений. Коллективы учреждений выросли, добавилось много внешних функций, в том числе взаимодействие с государственными и региональными органами власти, смежными учреждениями и общественными организациями, деятельность которых направлена на решение социальных проблем общества.

Социальная защита как важнейший механизм реализации социальной политики основывается на совокупности социальных и юридических гарантий, которые предоставляют каждому человеку реальные возможности реализации его прав, в том числе социально-экономических прав на такой уровень жизни, который необходим для нормального существования, развития личности и воспроизводства.

\section{Понятие социальной защиты населения и уровни правового обеспечения социального обслуживания \\ В Российской Федерации}

В свою очередь социальная защита населения функционирует сегодня как социальный институт. Фактически это комплексная система, формируемая для решения социальных проблем, помощи социально уязвимым социальным слоям и группам населения.

В.И. Жуков указывает, что социальная защита - это система принципов, правил, ме- тодов, законодательно установленных государством социальных гарантий; мероприятий и учреждений, обеспечивающих предоставление оптимальных условий жизни, удовлетворение потребностей, поддержание жизнеобеспечения и деятельного существования личности, различных социальных категорий и групп; совокупность мер, действий, средств государства и общества, направленных против ситуаций риска в нормальной жизни граждан (болезнь, безработица, старость, инвалидность, смерть кормильца и др.); комплекс государственных мер социально-экономического и правового характера по обеспечению гарантированного государством минимального уровня материальной поддержки социально уязвимых слоев населения в период экономических преобразований и связанного с этим снижения их уровня жизни [3, с. 283].

По мнению И.Г. Тарента, это также и совокупность законодательно установленных экономических, социальных, юридических гарантий и прав, а также социальных институтов и учреждений, обеспечивающих их реализацию и создающих условия для поддержания нормальной жизнедеятельности населения и, прежде всего, его социально уязвимых групп и слоев [4, с. 7].

На наш взгляд, сейчас можно говорить о двух уровнях правового обеспечения социального обслуживания почти во всех субъектах Российской Федерации: федеральном и региональном. Но не везде сформировалось достаточное правовое поле и «правовая технология», то есть определена сфера действия права в области социального обслуживания применительно к конкретной социально-экономической обстановке и произведен отбор пра- 
вовых структур и средств, способствующих рациональному и устойчивому развитию сети учреждений социальной защиты населения.

\section{Правовые основы системы социальной защиты населения}

В целом в России право граждан на социальную защиту гарантировано Конституцией и регламентировано российским законодательством. Так, в Конституции РФ Россия определяется как социальное государство, «политика которого направлена на создание условий, обеспечивающих достойную жизнь и свободное развитие человека». В нем «обеспечивается государственная поддержка семьи, материнства, отцовства и детства, инвалидов и пожилых граждан, развивается система социальных служб» (ст. 7 Конституции Российской Федерации).

Основной закон Российской Федерации устанавливает каждому гражданину гарантии социального обеспечения по возрасту, в случае болезни, инвалидности, потери кормильца, для воспитания детей и в иных случаях, установленных законом, поощряются добровольное социальное страхование, создание дополнительных форм социального обеспечения и благотворительность (ст. 39 Конституции РФ).

С 1995 г. органы социальной защиты населения получили прочную законодательную базу, на основе которой установлено правовое регулирование в области социального обслуживания населения [5, с. 28].

По нашему мнению, современную нормативно-правовую базу социальной защиты населения в Российской Федерации составляют:

1. Конституция (Основной Закон) Российской Федерации;

2. Федеральные законы:

- от 16.07.1999 № 165-Ф3 (ред. от 03.07.2016 № 250-Ф3) «Об основах обязательного социального страхования»;

- от 17.07.1999 № 178-Ф3 (ред. от 29.12.2015 № 388-Ф3) «О государственной социальной помощи»;

- от 28.12.2013 № 442-Ф3 (ред. от 21.07.2014) «Об основах социального обслуживания граждан в Российской Федерации»;
- от 24.11.1995 № 181-Ф3 (ред. от 01.06.2017 № 104-Ф3) «О социальной защите инвалидов в Российской Федерации»;

- от 19.04.1991 № 1032-1 (ред. 29.07.2017 № 235-Ф3) «О занятости населения в Российской Федерации»;

- от 15.05.1991 № 1244-1 (ред. от 28.12.2016 № 509-Ф3) «О социальной защите граждан, подвергшихся воздействию радиации вследствие катастрофы на Чернобыльской АЭС»;

- от 28.12.2013 № 400-Ф3 «О страховых пенсиях»;

- от 17.12.2001 № 173-Ф3 «О трудовых пенсиях в Российской Федерации» (согласно Федеральному закону от 28.12.2013 г. № 400-Ф3 настоящий Федеральный закон не применяется с 01.01.2015 г. за исключением норм, регулирующих исчисление размера трудовых пенсий и подлежащих применению в целях определения размеров страховых пенсий в соответствии с названным Федеральным законом в части, не противоречащей названному Федеральному закону);

- от 15.12.2001 г. № 166-Ф3 (ред. от 01.07.2017 № 148-Ф3) «О государственном пенсионном обеспечении в Российской Федерации» и других.

Важно также отметить Федеральный закон от 22.08.2004 г. № 122-Ф3, который изменил более 150 действующих нормативных актов, в том числе по вопросам социальной защиты. Целью его принятия явилась необходимость защиты прав и свобод граждан Российской Федерации на основе разграничения полномочий между федеральными органами государственной власти и органами государственной власти субъектов РФ, оптимизации деятельности территориальных органов исполнительной власти.

Основными положениями данного закона в области реформирования системы социальной защиты являются:

1) разделение льготников на «федеральных» и «региональных» в соответствии с полномочиями и расходными обязательствами Российской Федерации и ее субъектов;

2) «монетизация льгот», то есть замена льгот в натуральной форме «федеральным» льготникам на ежемесячную денежную выплату (ЕДВ); 


\section{ТЕОРИЯ И ПРАКТИКА ГОСУДАРСТВЕННО-ПРАВОВОГО РАЗВИТИЯ}

3) предоставление «федеральным» льготникам набора социальных услуг стоимостью 450 рублей в месяц, в состав которого входит: дополнительная бесплатная медицинская помощь, в том числе обеспечение лекарственными средствами, предоставление путевки на санаторно-курортное лечение при наличии медицинских показаний (400 рублей) и бесплатный проезд на пригородном железнодорожном транспорте, а также на междугороднем транспорте к месту лечения (50 рублей).

Сумма средств, предусмотренная на «социальный пакет», удерживается из состава начисления ежемесячной денежной выплаты (Постановление Правительства Российской Федерации от 24.11.2014 г. № 1236 «Об утверждении примерного перечня социальных услуг по видам социальных услуг»).

\section{Организационно-правовая характеристика деятельности социального работника}

Нельзя не сказать, что организация и координация социальной работы с отдельными лицами, категориями граждан и семьями, нуждающимися в социальной защите, осуществляется на основании Кодекса профессиональной этики работников органов социальной защиты (Приказ Министерства труда и социальной защиты Российской Федерации от 31.12.2013 г. № 792 «Об утверждении кодекса этики и служебного поведения работников органов управления социальной защиты населения и учреждений социального обслуживания»).

Отметим основные положения данного нормативного акта, регулирующие правовое положение работников социальных служб:

1) поведение и облик социального работника (сотрудник социальной службы должен поддерживать высокие нравственные стандарты своего поведения, исключая какие-либо уловки, введение кого-либо в заблуждение, нечестные действия, четко различая заявления и действия, сделанные им как частным лицом и как представителем профессии);

2) этические обязательства социального работника по отношению к клиентам (сотрудник социальной службы обязан уважать тайны клиентов и не распространять инфор- мацию, прошедшую в ходе профессиональной социальной помощи);

3) этические нормы социального работника по отношению к своим коллегам (социальный работник должен обращаться с коллегами с уважением, вежливостью, справедливо, с доверием, соблюдая деликатность и справедливость, должен обращаться с клиентами своих коллег внимательно, вести их дела с полной профессиональной отдачей);

4) этические обязательства социального работника по отношению к руководителю или руководящей организации (сотрудник социальной службы должен твердо придерживаться своих обязательств, данных руководящей организации);

5) этические обязательства социального работника перед своей профессией (социальный работник должен поддерживать и повышать значимость, этику, знания и цели своей профессии, вкладывать свое время, профессиональный опыт и знания в деятельность, способствующую уважительному отношению к полезности, чистоте и компетентности своей профессии);

6) этические обязательства социального работника перед обществом (сотрудник социальной службы должен содействовать развитию благосостояния общества) (Приложение к приказу Министерства труда и социальной защиты РФ от 31.12.2013 г. № 792 «Кодекс этики и служебного поведения работников органов управления социальной защиты населения и учреждений социального обслуживания»).

\section{Выводы}

Итак, как отмечено в Кодексе этики и служебного поведения работников органов управления социальной защиты населения и учреждений социального обслуживания, социальный работник - представитель особой, деликатной и гуманной профессии. Посредник связующее звено во взаимосвязи личности, семьи и общества, он призван работать в системе служб социальной помощи населению, обеспечивая медико-психолого-педагогическую и правовую целесообразность этой системы, решая в органическом единстве задачи воспитания взрослых и детей, укрепления нравственности, физического и психического здоровья, правовой и экономической защиты, организации труда и досуга, оказания своевре- 
менной социальной помощи семьям и лицам, особо в ней нуждающимся (Кодекс этики и служебного поведения работников органов управления социальной защиты населения и учреждений социального обслуживания).

Вся действующая система социальной защиты населения реализует свои цели и задачи посредством и в рамках сложившихся организационно-правовых форм. В России сложилась многоукладная организационная структура системы социальной защиты населения, в которой используются практически все организационно-правовые формы, существующие в странах с рыночной экономикой, хотя нередко они функционируют в неполную силу из-за нерешенности ряда теоретических и организационных проблем [5, с. 76].

Ведущими организационно-правовыми формами социальной защиты населения в настоящее время являются: государственное социальное страхование; пенсионное обеспечение; социальное обслуживание; организация занятости населения; обеспечение особо нуждающихся категорий населения социальными пособиями, льготами [4, с. 27].

Отмечается, что дальнейшее развитие системы социальной защиты населения в России должно быть направлено на:

- активизацию разработки теории и практики социальной защиты, теоретическое обоснование ее целей и задач, способов деятельности и организационных структур, дальнейшее формирование правовых норм деятельности в данной сфере;

- совершенствование социальной политики в области социальной защиты населения за счет принятия конкретных политических решений в области помощи и поддержки социально уязвимых групп населения и, прежде всего, семьи и детей;

- обеспечение потребности граждан старшего возраста, инвалидов, включая детейинвалидов, семей и детей в социальном обслуживании;

- совершенствование и всемерное укрепление системы социального обслуживания как важнейшего направления социальной защиты, включая его правовое, финансовое, организационно-управленческое, кадровое, материально-техническое, научно-методическое, информационное обеспечение;
- создание благоприятных условий для жизнедеятельности семьи, функционирования института семьи, рождения детей;

- концентрацию материальных, финансовых, интеллектуальных ресурсов для обеспечения гарантированных Конституцией и законами социальных норм, осуществления социальных гарантий на всех уровнях жизнедеятельности российского общества;

- поддержка развития социального обслуживания в нестационарных учреждениях различного вида;

- повышение качества социальных услуг;

- формирование законченных социальных технологий в работе с социально уязвимыми группами [4, с. 29].

Таким образом, вопросы правового обеспечения социальной защиты населения и современной системы социального обслуживания в России очень актуальны. Принципы социальной защиты реализуются посредством разработки и совершенствования законодательной базы как отраслевого, так и межотраслевого характера. В Российской Федерации по-прежнему сохраняется обширная и разветвленная система льгот. Только через органы социальной защиты населения осуществляется реализация льгот для социально незащищенных категорий населения в рамках рассмотренных нами федеральных законов. Государство проводит линию на необходимость учета социальных проблем в процессе разработки проектов федеральных законов в области структурной перестройки, финансирования и налогообложения, приватизации, постановлений правительства по вопросам развития отраслей и регионов Российской Федерации.

\section{СПИСОК ЛИТЕРАТУРЫ}

1. Маяцкая, И. Н. Экономические основы социальной работы : учебник для бакалавров / И. Н. Маяцкая. -М. : ИТК Дашков иК, 2013. - 264 с.

2. Павленок, П. Д. Теория, история и методика социальной работы. Избранные работы : учеб. пособие / П. Д. Павленок. - 10-е изд., испр. и доп. М. : ИТК Дашков и К, 2015. - 592 с.

3. Социальная защита / под ред. акад. РАН В. И. Жукова // Современная энциклопедия социальной работы. - 2-е изд., доп. и перераб. - М. : Изд-во РГСУ, 2008. - С. 412. 


\section{ТЕОРИЯ И ПРАКТИКА ГОСУДАРСТВЕННО-ПРАВОВОГО РАЗВИТИЯ}

4. Тарент, И. Г. Система социальной защиты населения в Российской Федерации : учеб. пособие / И. Г. Тарент, С. А. Юдников. - Изд. 3-е, испр. и доп. - Ногинск : Ногинский фил. РАНХиГС, 2015. $160 \mathrm{c}$.

5. Холостова, Е. И. Генезис социальной работы в России : учеб. пособие / Е. И. Холостова. - М. : Дашков и К, 2015. - 230 с.

\section{REFERENCES}

1. Mayatskaya I.N. Ekonomicheskie osnovy sotsialnoy raboty [Economic Fundamentals of Social Work]. Moscow, ITK Dashkov i K Publ., 2013. 264 p.
2. Pavlenok P.D. Teoriya, istoriya i metodika sotsialnoy raboty. Izbrannye raboty [Theory, History and Methodology of Social Work. Selected Works]. Moscow, ITK Dashkov i K Publ., 2015. 592 p.

3. Zhukov V.I., ed. Sotsialnaya zashchita [Social Protection]. Sovremennaya entsiklopediya sotsialnoy raboty [Modern Encyclopedia of Social Work]. Moscow, Izd-vo RGSU, 2008, p. 412.

4. Tarent I.G., Yudnikov S.A. Sistema sotsialnoy zashchity naseleniya $v$ Rossiyskoy Federatsii [The System of Social Protection of the Population in the Russian Federation]. Noginsk, Noginskiy fil. RANKhiGS, 2015. 160 p.

5. Kholostova E.I. Genezis sotsialnoy raboty v Rossii [Genesis of Social Work in Russia]. Moscow, Dashkovi K Publ., 2015. 230 p.

\section{Information about the Authors}

Yulia S. Gusakova, Associate Professor, Department of Labor and Entrepreneurial Law, Belgorod State National Research University, Pobedy St., 85, 308015 Belgorod, Russian Federation, Gusakova@bsu.edu.ru.

Vladislav Yu. Turanin, Associate Professor, Department of Labor and Entrepreneurial Law, Belgorod State National Research University, Pobedy St., 85, 308015 Belgorod, Russian Federation, Turanin@bsu.edu.ru.

\section{Информация об авторах}

Юлия Сергеевна Гусакова, доцент кафедры трудового и предпринимательского права, Белгородский государственный национальный исследовательский университет, ул. Победы, 85, 308015 г. Белгород, Российская Федерация, Gusakova@bsu.edu.ru.

Владислав Юрьевич Туранин, доцент кафедры трудового и предпринимательского права, Белгородский государственный национальный исследовательский университет, ул. Победы, 85, 308015 г. Белгород, Российская Федерация, Turanin@bsu.edu.ru. 